PRECIPITATION REACTIONS AND STABILITY

OF $\mathrm{Ni}_{3} \mathrm{Cb}$ IN INCONEL ALLOY 718

\author{
W. J. Boesch* \\ H. B. Canada**
}

\begin{abstract}
Data presented in current literature attribute many desirable properties of Inconel Alloy 718 to sluggish precipitation of the columbium rich intermeta11ics. Original time-temperaturetransformation curves indicate the precipitation of $\mathrm{Ni}_{3} \mathrm{Cb}$ initiated in five to ten hours in the temperature range commonly used for solution heat treatment. This presentation shows that $\mathrm{Ni}_{3} \mathrm{Cb}$ precipitates in less than 0.2 hours at $1700^{\circ} \mathrm{F}$. The chemical composition and structure for $\mathrm{Ni}_{3} \mathrm{Cb}$ are presented. The chemical and morphological stability of this phase are discussed. The change from the spheroldal hardening precipitate to the acicular $\mathrm{Ni}_{3} \mathrm{Cb}$ is also shown.

The presentation also discusses the composition and stability of the MC carbide and indicates the precipitation of CbC. The precipitation of $\mathrm{Ni}_{\mathrm{X}} \mathrm{Cb}$ and its upper stability limit are discussed.
\end{abstract}

* W. J. Boesch is Senior Research Metallurgist, Special Metals Corporation, New Hartford, New York

** H. B. Canada is Senior Research Chemist, Special Metals Corporation, New Hartford, New York 
Introduction:

Precipitation reactions in Inconel Alloy 718 have been described as sluggish. Eiselstein(1) was the first to prepare timetemperature-transformation curves to explain the behavior of the major precipitation reactions. These data were reviewed and the $\mathrm{Ni}_{3} \mathrm{Cb}$, Laves phase and gamma prime transformation curves are reproduced in Figure 1. Al1 specimens used by Eiselstein were aged in an csscntially strain-free condition which was produced by a one hour solution heat treatment at $2100^{\circ} \mathrm{F}$. As depicted the $\mathrm{Ni}{ }_{3} \mathrm{Cb}$ phase has a relatively slow aging response and begins to precipitate in approximately 5 hours at $1650^{\circ} \mathrm{F}$. Time-temperature-transformation data presented by Wagner ${ }^{(2)}$ indicate an even slower aging response with initiation of $\mathrm{Ni}_{3} \mathrm{Cb}$ precipitation in about 10 hours at $1650^{\circ} \mathrm{F}$. According to the Eiselstein curves, Laves phase has a faster aging response and begins to develop in about 50 minutes at $1750^{\circ} \mathrm{F}$. If the commonly used one hour solution heat treatment in the temperature range of $1700^{\circ} \mathrm{F}$ to $1750^{\circ} \mathrm{F}$ is considered, the early transformation curves predict freedom from $\mathrm{Ni}_{3} \mathrm{Cb}$ precipitation. In addition the data predict the formation of sma11 amounts of Laves phase with the same heat treatment. The curves also show the gamma prime reaction to be the fastest with precipitation occurring in about 6 minutes at $1400^{\circ} \mathrm{F}$.

Recent metallographic observations (3) are inconsistent with the predictions from the early transformation curves. Various quantities of $\mathrm{Ni}_{3} \mathrm{Cb}$ were detected in specimens subjected to heat treatments of less than 5 hours at $1700^{\circ} \mathrm{F}$. Therefore, this investigation was initiated to study the aging behavior of $\mathrm{Ni}_{3} \mathrm{Cb}$ in essentially strainfree material with the objective of developing a more precise timetemperature-transformation curve which might resolve the observed discrepancies. During the execution of the program, other related reactions were detected and studied. In addition, the stability of various phases during long time elevated temperature exposure was determined.

Experimenta1 Procedure:

Standard commercial 19/32-inch diameter hot rolled bar was used in this investigation. The original ingot was a product of a vacuum induction melting plus vacuum arc remelting technique. The ingot was cogged to reroll stock and then rolled to finished bar at a starting temperature of $2050^{\circ} \mathrm{F}$ and a finishing temperature of $1850^{\circ} \mathrm{F}$. The chemical composition of the product which is listed in Table $I$ is well within the compositional range defined in many Incone 1 Alloy 718 specifications. To assure that the material used is representative of commercial quality, its properties were compared with the requirements of an arbitrarily selected specification. The tensile data presented in Table I confirm that the material has acceptable mechanical strength. Metallographically examined samples were found free of deleterious banding and segregation.

Upon completion of quality assurance tests, the bar was cut into three inch long heat treatment specimens. A11 bars were solution heat treated for 4 hours at $1950^{\circ} \mathrm{F}$ and air cooled to produce an essen- 
tially strain-free condition which was verified by $\mathrm{x}$-ray. Thermocouples embedded in the bars indicated a cooling rate of $2.7^{\circ} \mathrm{F}$ per second. One specimen was retained in the as-solution heat treated condition as a control and the remainder were aged in accordance with the program depicted in Figure 2. A11 specimens aged for one hour or more were heat treated in air in a conventional laboratory furnace. Specimens aged for less than one hour were heat treated in a salt pot furnace to obtain fast heating rates and thus minimize timing error.

After heat treatment the specimens were sectioned to provide 1ight microscopy, electron microscopy, and phase extraction samples. The light microscopy samples were also used as hardness samples.

Two bars approximately 6 inches in length were solution heat treated for 4 hours at $1950^{\circ} \mathrm{F}$ and air cooled followed by a gradient $\left(1100^{\circ} \mathrm{F}\right.$ to $\left.2040^{\circ} \mathrm{F}\right)$ heat treatment for 48 and 100 hours respectively. These bars were stress-free ground and hardness tested to provide supplementary data.

Samples for both light and electron microscopy were mechanically ground through 600 grit paper and polished with Linde A alumina abrasive. This was followed by a ten second electropolish in a solution of one part sulfuric acid to six parts methanol. The majority of samples were electro-etched in $10 \mathrm{v} / \mathrm{o}$ hydrochloric acidmethanol solution for ten to thirty seconds, depending upon the quantity of intermetallic compounds present in the structure. Samples containing only large amounts of $\mathrm{Ni}_{3} \mathrm{Cb}$ plates were electroetched for two to four seconds in a solution of chromic acid in dilute sulfuric acid. This technique gave better resolution of the $\mathrm{Ni}_{3} \mathrm{Cb}$ plates.

Al1 light microscopy samples were photographed at 1000X using an oil immersion lens with a 1.25 numerical aperture. Samples for electron microscopy were replicated with collodion, shadow cast with chromium and backed with a thin deposit of carbon. The representative surfaces were photographed at 1500X and enlarged to $7500 \mathrm{x}$.

The procedures for extracting the precipitated phases are similar to those used to extract phases in Udimet 700 and are described in a previous publication $(4)$. A chemical attack with a $10 \mathrm{v} / \mathrm{o}$ bromine-methanol solution was employed for the isolation of (CbTi)C carbide, $\mathrm{TiN}$, and $\mathrm{Ti}_{2} \mathrm{SC}$. The $\mathrm{Ni}_{3} \mathrm{Cb}$ and carbide were coextracted electrolytically in a $10 \mathrm{v} / 0$ hydrochloric acid-methanol solution using a current density of 0.07 amps per square centimeter. An electrolytic extraction at 0.1 amps per square centimeter in a solution of 2 parts hydrochloric acid, 9 parts methanol, and 9 parts water was used to cxtract the transition phase $\mathrm{Ni} \mathrm{Cb}$. Extraction times were limited to a four hour period or less depending on the amount of residue required for analysis. Samples for all extraction techniques were weighed before and after the extraction. The residues were 
collected on a tared solvent-resistant membrane filter, washed in methanol, air dried, and weighed. The electrolytic extraction apparatus consists of water cooled cells equipped with Teflon stop-cocks at the bottom for draining the residue and electrolyte as illustrated in Figure 3.

To detect trace amounts of $\mathrm{Ni}_{3} \mathrm{Cb}$, the electrolyte and residue from the hydrochloric acid-methanol extraction were allowed to settle for approximately two hours. The solution containing the sma11 $\mathrm{Ni}_{3} \mathrm{Cb}$ particles was decanted from the settled MC carbide and filtered through a solvent-resistant membrane filter. The filter pad containing the residue was mounted on a glass slide using double adhesive cellophane tape. The residue was sealed to the slide with 10 mil Mylar. A Phillips Diffractometer equipped with a monochromator was used to obtain traces for identification of phases.

Sma11 portions of the extracted residues were mounted on glass slides using a $1 \mathrm{v} / \mathrm{o}$ solution of Formvar-ethylene dichloride as specimens for light microscopy. Standard chemical procedures were used to analyze the residues. The MC chemistries were determined from the bromine residues while the combined $\mathrm{MC}$ plus $\mathrm{Ni}_{3} \mathrm{Cb}$ chemistries were determined from the electrolytic residues. The $\mathrm{Ni}_{3} \mathrm{Cb}$ chemistries were calculated by difference.

Discussion of Results:

The major phases detected in this study by microscopy, $x$-ray, and/or chemical analysis were $\mathrm{Ni}_{3} \mathrm{Cb}, \mathrm{Ni}_{\mathrm{x}} \mathrm{Cb}, \mathrm{MC}$, and gamma prime. The compositions and structures of these phases are listed in Table II. The morphologies of some phases are depicted in Figure 4. The platelike form of $\mathrm{Ni}_{3} \mathrm{Cb}$ is confirmed in Figure 4C. This residue from a hydrochloric acid-methanol extraction also contains ( $\mathrm{Cb}, \mathrm{Ti}$ ) C and $\mathrm{TiN}$ particles. Typica1 ( $\mathrm{Cb}, \mathrm{Ti}$ ) C particles are shown in Figure 4B. This residue which was extracted from a solution heat treated specimen also contains TiN particles. These particles have a more cubic morphology than the carbides and are bright yellow-orange in color. Chemical analysis of the residue indicates that the residue contains about $2 \mathrm{w} / \mathrm{o}$ TiN. Some particles are probably of the carbo-nitride type since they are lightly tinted orange. Specimens solution heat treated and then aged develop a fine almost plate-like precipitate (Figure 4C) which is recovered in the bromine-methanol extracted residue. This phase is believed to be $\mathrm{CbC}$ as reported by Cremisio et al(5). Gamma prime was detected only by metallographic techniques. The structure of this phase has not been resolved and has been reported as both BCT $(2,6)$ and FCC $(1,7)$. Gamma prime was not isolated in this investigation because primary interest centered upon $\mathrm{Ni}_{3} \mathrm{Cb}$ reactions.

The data given in Figure 5 show the weight percent of $\mathrm{Ni} 3 \mathrm{Cb}$ determined in each heat treated condition. A trace amount of $\mathrm{Ni}_{3} \mathrm{Cb}$ was detected after 0.2 hours exposure at $1700^{\circ} \mathrm{F}$. No $\mathrm{Ni}_{3} \mathrm{Cb}$ was found at $1850^{\circ} \mathrm{F}$ and above or at $1200^{\circ} \mathrm{F}$ and below even at 2000 hour exposures. At $1700^{\circ} \mathrm{F}$ and above on $1 \mathrm{y} \mathrm{Ni}_{3} \mathrm{Cb}$ forms. There is one area which is outlined near the 48 hour $-1800^{\circ} \mathrm{F}$ position. In this area the amount of 
$\mathrm{Ni}_{3} \mathrm{Cb}$ detected by $\mathrm{x}$-ray and chemical analys is does not agree with microscopic observations. The $x$-ray diffraction shows a slight change in lattice parameters but there is no detectable change in chemistry of the extracted residue. Although there is no clear explanation for this observation, the region is probably a zone in which the $\mathrm{Ni}_{3} \mathrm{Cb}$ has a slight change in structure.

Typica1 structural changes which occur during the $1700^{\circ} \mathrm{F}$ exposure are shown in Figure $6 . \mathrm{Ni}_{3} \mathrm{Cb}$ first precipitates at twin or grain boundaries and often grows in a cell-1ike manner. A full Widmanstätten structure develops during a 24 hour exposure. Beyond 24 hours exposure there is an obvious growth in plate size. Aside from the minor structural change previously described, $\mathrm{Ni}{ }_{3} \mathrm{Cb}$ is stable and has a constant chemistry to at least 1000 hours exposure at $1600^{\circ} \mathrm{F}$.

The 48 hour and 100 hour hardness curves from the gradient bars are the same as shown in Figure 7. Hardness behavior is norma 1 except in the temperature range $1575^{\circ} \mathrm{F}$ to $1675^{\circ} \mathrm{F}$. This plateau and the abrupt drop in hardness at $1675^{\circ} \mathrm{F}$ indicates a phase change. At $1600^{\circ} \mathrm{F}$ there is a marked decrease in the amount of $\mathrm{Ni} 3 \mathrm{Cb}$ recovered by extraction and the amount observed metallographically. As shown in Figure 8 this is caused by a fine plate-1ike phase which was identified by $\mathrm{x}$-ray diffraction as the $\mathrm{BCT}$ phase $\mathrm{Ni} \mathrm{x}_{\mathrm{X}} \mathrm{Cb}$. The composition of this phase is currently under investigation. Specimens exposed for 500 hours or more at $1600^{\circ} \mathrm{F}$ had no $\mathrm{NixCb}$. A line placed at $1650^{\circ} \mathrm{F}$ on the $\mathrm{Ni3} \mathrm{Cb}$ TTT curve in Figure 5 indicates the approximate $\mathrm{Ni} \times \mathrm{Cb}$ stability limit.

Structural details of changes in gamma prime, $\mathrm{Ni} \mathrm{Cb}$, and $\mathrm{Ni} 3 \mathrm{Cb}$ morphologies are shown in Figure 9. After 1 hour exposure at $1600^{\circ} \mathrm{F}$ the predominant phases are fine gamma prime and $\mathrm{Ni} \times \mathrm{Cb} . \mathrm{A}$ moderately large amount of $\mathrm{Ni}_{3} \mathrm{Cb}$ can be seen at the grain boundaries. After 100 hours exposure at $1600^{\circ} \mathrm{F}$, the predominant phases are coarse $\mathrm{Ni}_{x x} \mathrm{Cb}$ and $\mathrm{Ni}_{3} \mathrm{Cb}$ plates. Only a few very large gamma prime particles remain in the structure. Figure 10 reveals a large amount of gamma prime, $\mathrm{Ni}_{\mathrm{x}} \mathrm{Cb}$, and $\mathrm{Ni}{ }_{3} \mathrm{Cb}$ after 100 hours exposure at $1450^{\circ} \mathrm{F}$. On $1 \mathrm{y}$ very fine gamma prime is present after 100 hours exposure at $1250^{\circ} \mathrm{F}$.

\section{Summary and Conclusions:}

The MC phase has the composition ( $\left.\mathrm{Cb}, 85^{\mathrm{Ti}}, 15\right) \mathrm{C}$ and is stable within the parameters studied. There is an indication of $\mathrm{CbC}$ precipitation in less than 2 hours exposure at $1600^{\circ} \mathrm{F}$.

The structures indicate that the spheroidal gamma prime changes to $\mathrm{Ni}_{\mathrm{X}} \mathrm{Cb}$ which in turn changes to $\mathrm{Ni}_{3} \mathrm{Cb}$ at temperatures above $1200^{\circ} \mathrm{F}$ and below about $1650^{\circ} \mathrm{F}$. The approximate upper stability limit for $\mathrm{Ni} \mathrm{Cb}$ was determined. In contrast with previous publications (1) no laves phase was found to precipitate within the time-temperature parameters studied.

$\mathrm{Ni}_{3} \mathrm{Cb}$ has the composition $\mathrm{Ni}_{3}\left(\mathrm{Cb}, 8^{\mathrm{Ti}} .2\right)$ and precipitates much faster than indicated in previous investigations as shown in Figure 11. 
Since $\mathrm{Ni3} C b$ may precipitate in strain-free samples in about 6 minutes at $1700^{\circ} \mathrm{F}$, it may be present in material commercially heat treated in this temperature range. Therefore, heat treatments below $1850^{\circ} \mathrm{F}$ should not be considered absolute solution heat treatments for Inconel A1loy 718 . 


\section{REFERENCES}

1. H. L. Eiselstein, Metallurgy of a Columbium-Hardened Nicke1Chromium-Iron Alloy, ASTM Special Technical Publication No. 369, 1965, pp. 62-79.

2. H. J. Wagner and A. M. Hal1, Physical Metallurgy of Alloy 718, Defense Metal Information Center, Report No. 217, Battelle Memorial Institute, Columbus, Ohio, June, 1965.

3. W. B. Aufderhaar and R. S. Cremisio, Some Structural Aspects of Thermomechanically Treated 718 Alloy, paper presented at the AIME Thermomechanical Treatment of Nicke1-Base Superalloys Symposium at the National Metals Congress, Cleveland, Ohio, October 17, 1967.

4. W. J. Boesch and H. B. Canada, Phases Present in the Wrought Superalloy Udimet 700, Journal of Metals, 20, April 1968, pp. 46-50.

5. R. S. Cremisio et a1, The Effect of Thermomechanical History on the Stability of A1loy 718, paper presented at the International Symposium on Structural Stability in Superalloys, Seven Springs, Pennsylvania, September 4, 1968.

6. E. L. Raymond, Effect of Grain Boundary Denudation of Gamma Prime on Notch-Rupture Ductility of Inconel Nicke1-Chromium Alloys $\mathrm{X}-750$ and 718 , Transactions of the Metallurgical Society of AIME, 239,1967 , pp. 1415-1422.

7. J. F. Barker et al, Effect of Long Time Exposure on Incone1 718, paper presented at the ASM Thermal Stability Symposium at the National Metals Congress, Cleveland, Ohio, October 16, 1967. 
Table I

CHEMISTRY AND PROPERTIES OF HEAT 7-3516

Chemical Composition

$\underline{\mathrm{Ni}}$

$\underline{\mathrm{Cr}}$

Mo

$\underline{\mathrm{Cb}+\mathrm{Ta}}$

$\underline{\mathrm{Ti}}$

53.8

18.0

3.00

5.24

1.00

A1

0.59

$\frac{\mathrm{C}}{0.05}$

$\underline{\mathrm{S}}$

B

0.004

Fe

0.003

Ba1.

Tensile Properties

\begin{tabular}{lcccc} 
Temp. & UTS & $\begin{array}{c}0.2 \text { YS } \\
(\mathrm{Ksi})\end{array}$ & $\begin{array}{c}\text { Elong. } \\
(\%)\end{array}$ & $\begin{array}{l}\text { R.A. } \\
(\%)\end{array}$ \\
\hline
\end{tabular}

$\begin{array}{llllll}\text { Spec. } & \text { R.T. } & 180.0 & 150.0 & 12 & 15 \\ 7-3516 & \text { R.T. } & 206.0 & 172.0 & 25.6 & 44.0 \\ & & & & & \\ \text { Spec. } & 1200 & 145.0 & 125.0 & 10 & 15 \\ 7-3516 & 1200 & 166.0 & 142.0 & 28.3 & 32.6\end{array}$

Table II

IDENTIFICATION OF PHASES

$\begin{array}{ccc}\text { Phase } & \frac{\text { Composition }}{(\text { Atomic Ratio })} & \text { Structure } \\ \mathrm{Ni}_{3} \mathrm{Cb} & \mathrm{Ni}_{3}\left(\mathrm{Cb} \cdot 8^{\mathrm{Ti}} \cdot 2\right) & \text { Orthorhombic } \\ \mathrm{MC} & \left(\mathrm{Cb} \cdot 85^{\mathrm{Ti}} \cdot 15^{\mathrm{C}}\right) \mathrm{C} & \mathrm{FCC} \\ \mathrm{Ni}_{\mathrm{X}} \mathrm{Cb} & -\ldots & \mathrm{BCT} \\ \text { Gamma Prime } & \mathrm{Ni}_{3}(\mathrm{~A} 1, \mathrm{Ti}, \mathrm{Cb}) & \mathrm{FCC}-\mathrm{BCT}\end{array}$




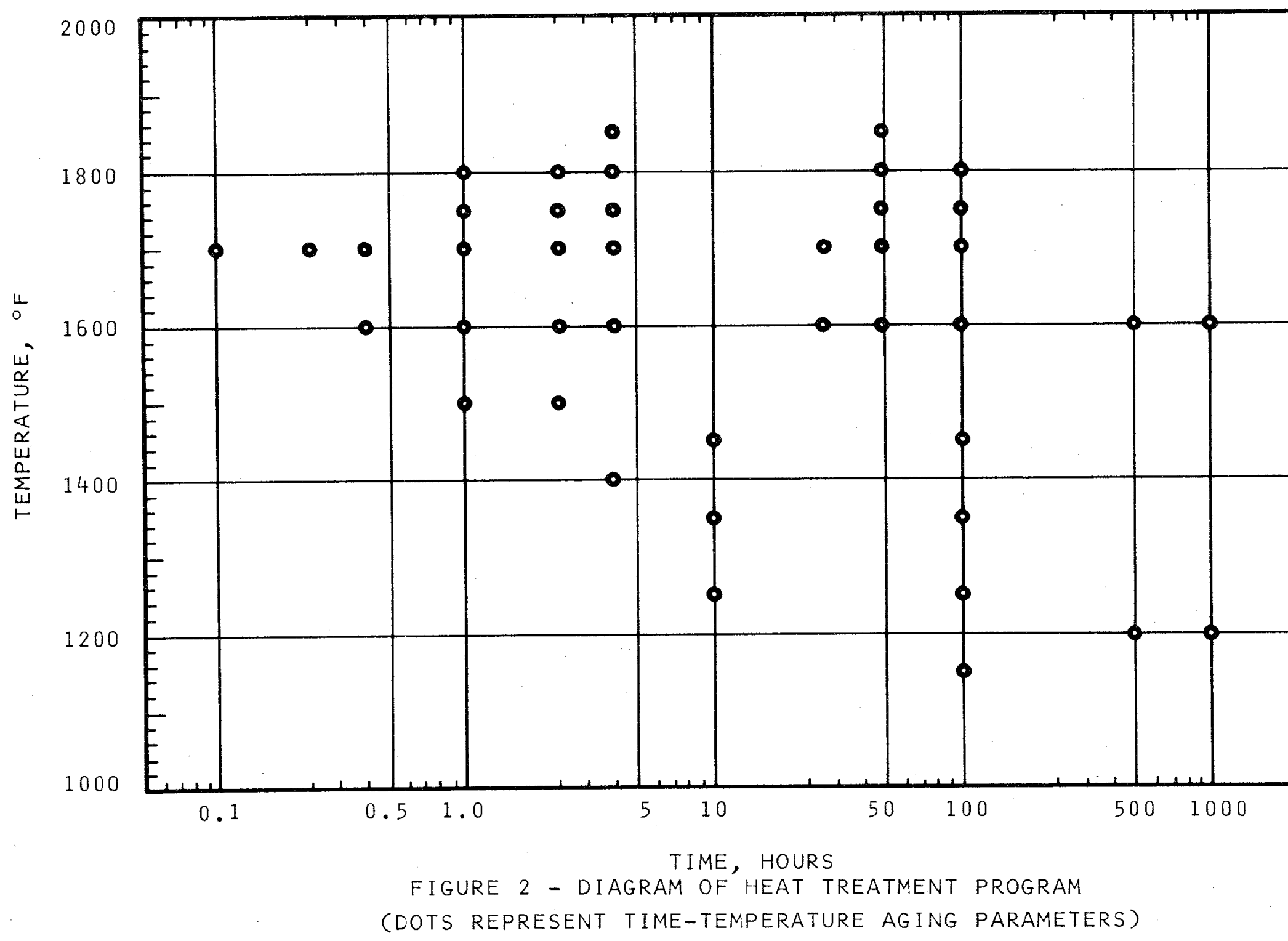




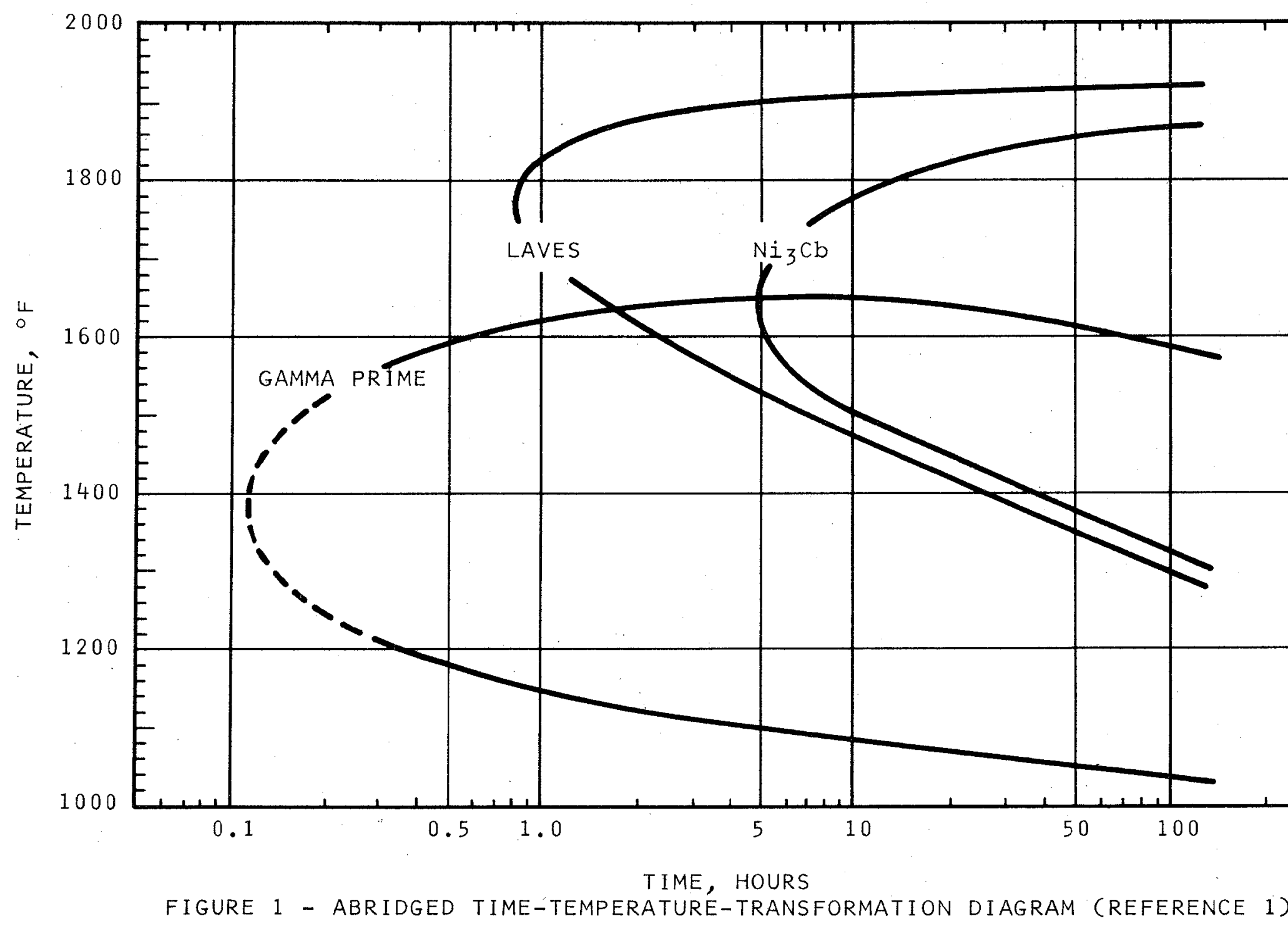


$x$
$x$
2
$N$
$n$
1
2

FIGURF 3

ELECTROLYTIC EXTRACTION APPARATUS

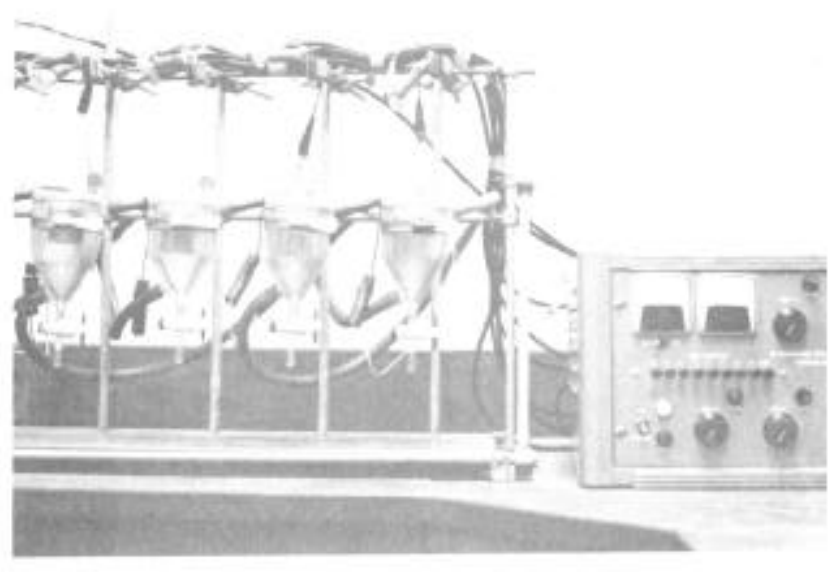

FIGURE 4 - EXTRACTED RESIDUES

$4 \mathrm{~A} \mathrm{Ni}_{3} \mathrm{Cb},(\mathrm{Cb}, \mathrm{Ti}) \mathrm{C}$, AND TIN; HCI-METHANOL EXTRACTION

4B (CD,TI)C, AND TIN; Br2METHANOL EXTRACTION

$4 \mathrm{C}(\mathrm{Cb}, \mathrm{T} I) \mathrm{C}, \mathrm{TIN}, \mathrm{AND} \mathrm{CbC}$; Br, - METHANOL EXTRACTION

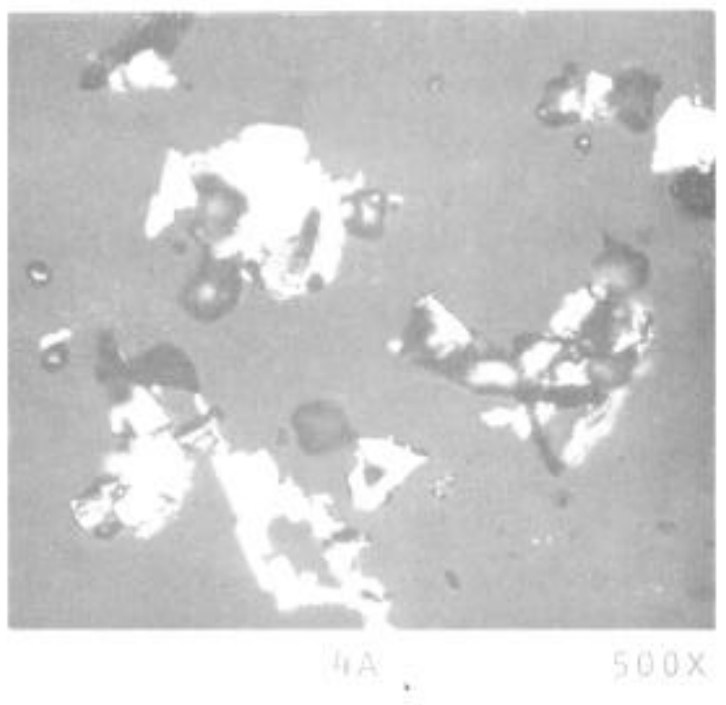

$19500 F-4 H R S-A C+17000 F-100 H R S-A C$
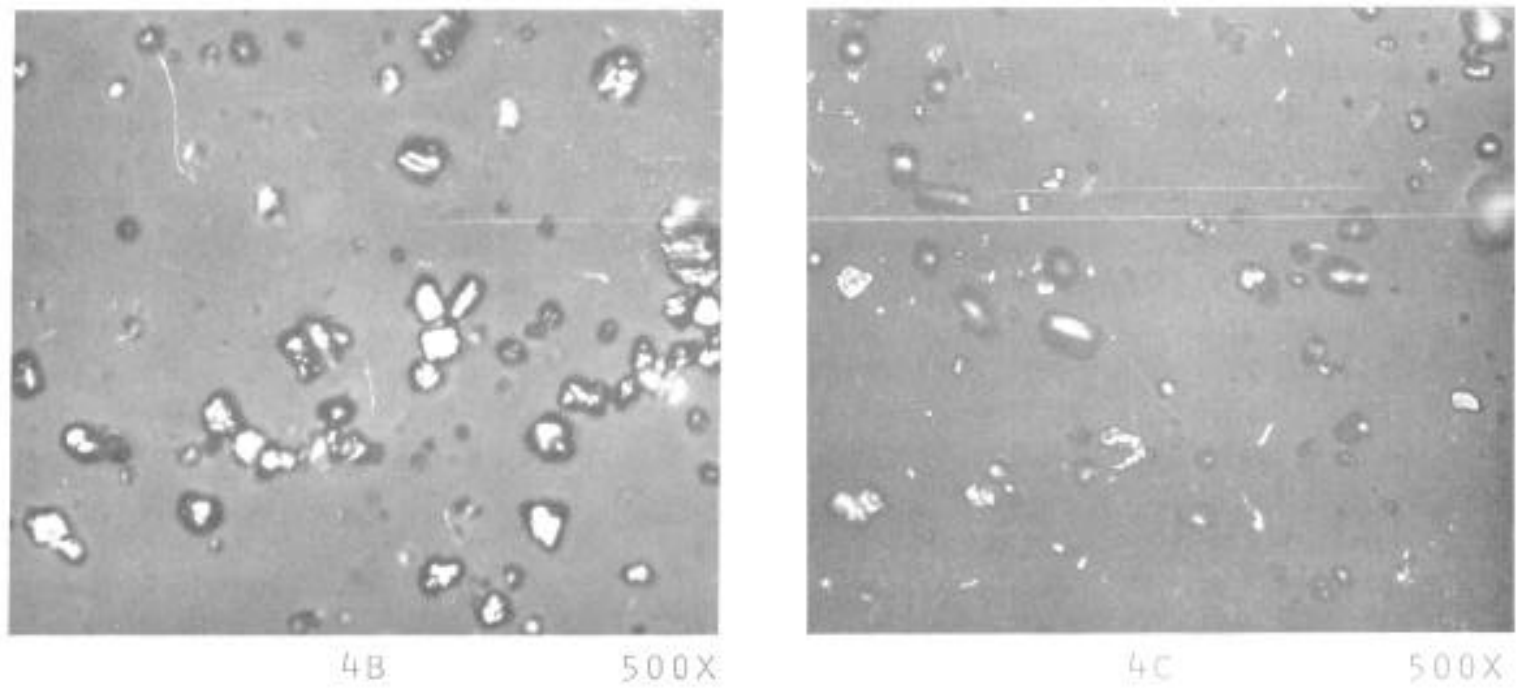

$1950^{\circ} \mathrm{F}-4 \mathrm{HR} 5-\mathrm{AC}$

$19500 \mathrm{~F}-4 \mathrm{H} R \mathrm{~S}-\mathrm{AC}+16009 \mathrm{~F}-2 \mathrm{HRS}-\mathrm{AC}$ 


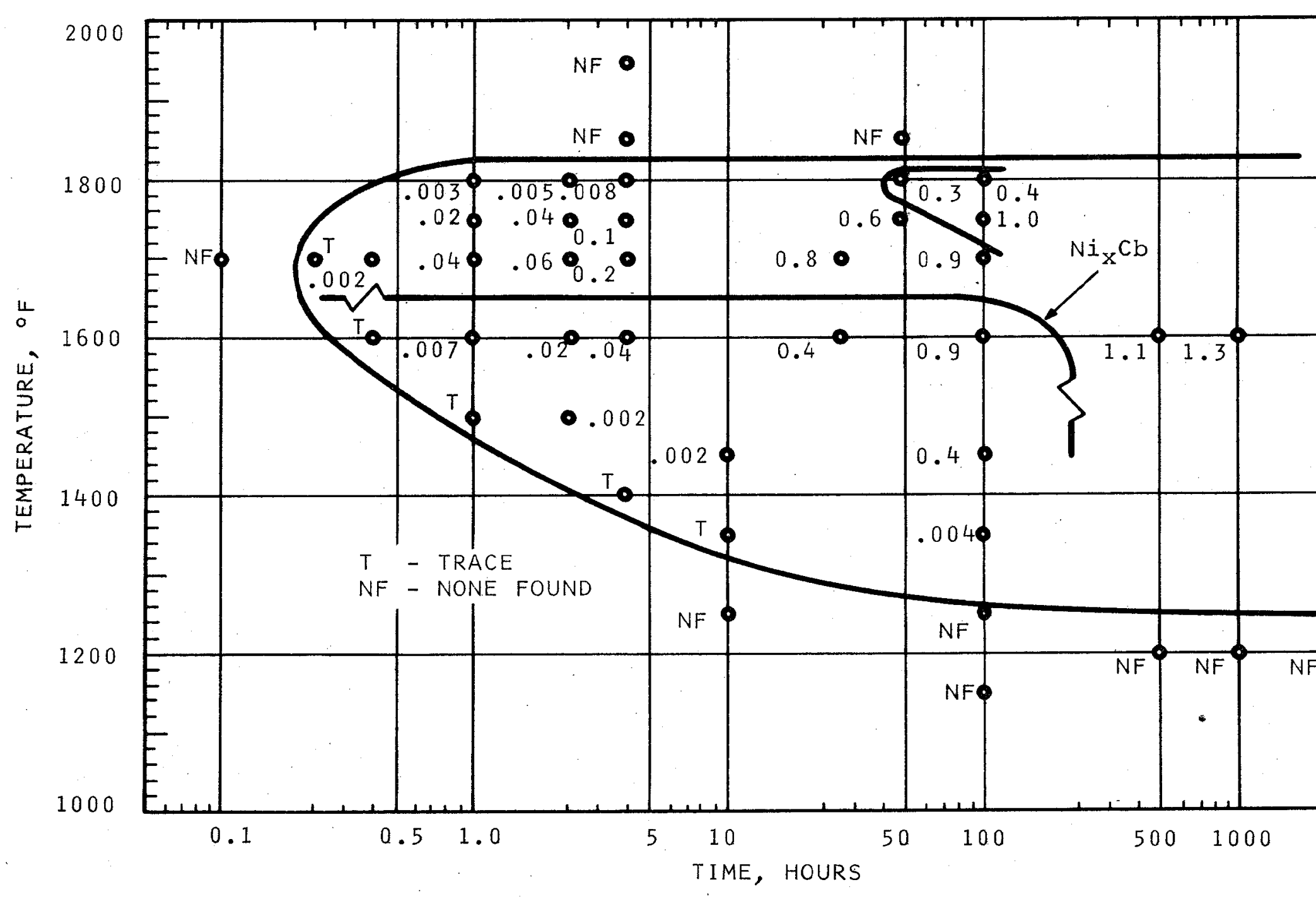

FIGURE 5 - $\mathrm{Ni}_{3} \mathrm{Cb}$ TTT CURVE AND QUANTITATIVE EXTRACTION DATA 

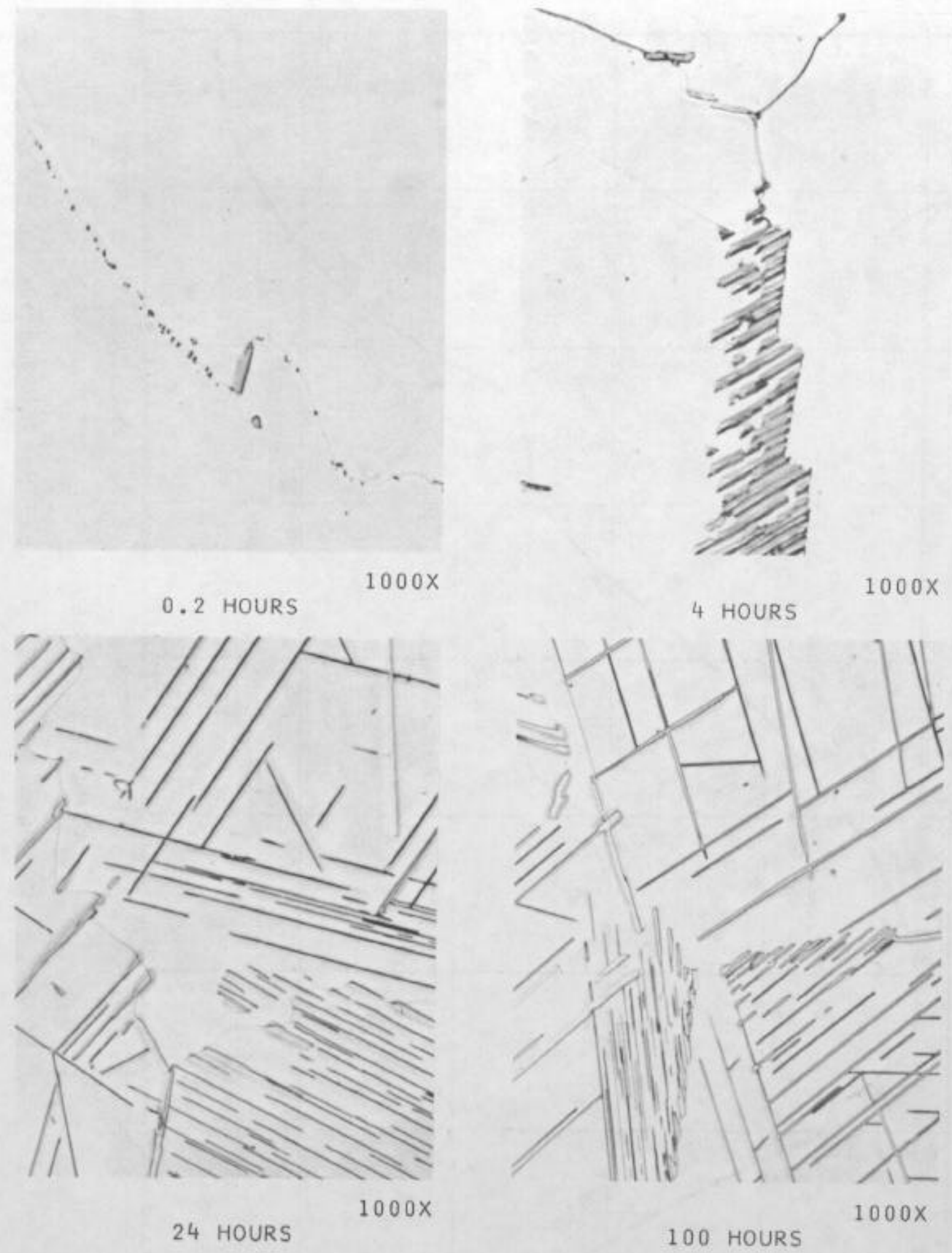

FIGURE 6

EFFECT OF $1700^{\circ} \mathrm{F}$ EXPOSURE UPON $\mathrm{Ni}{ }_{3} \mathrm{Cb}$ PRECIPITATION 


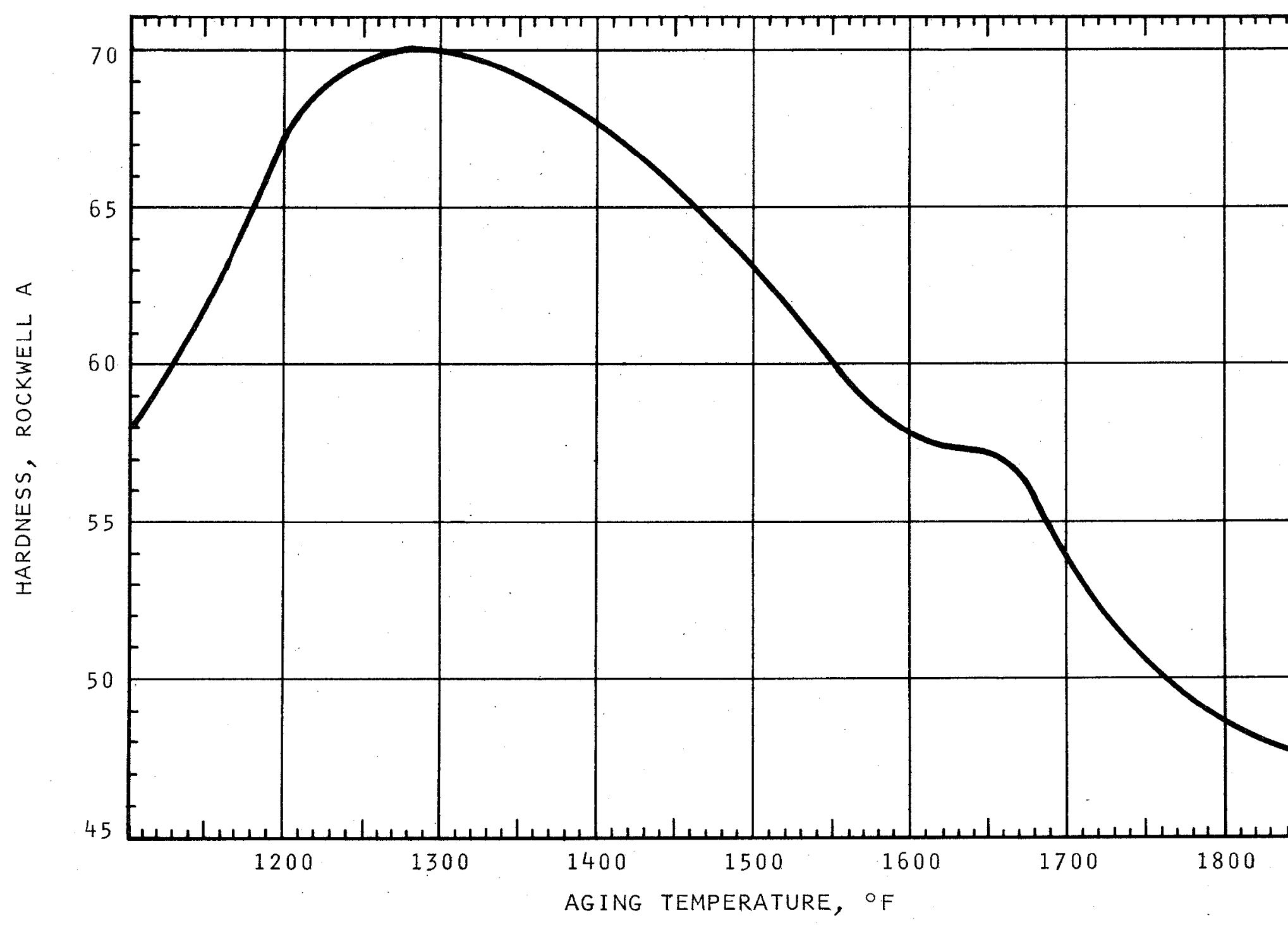

FIGURE 7 - HARDNESS OF GRADIENT HEAT TREATED BARS 
$v$
2
1
1
1

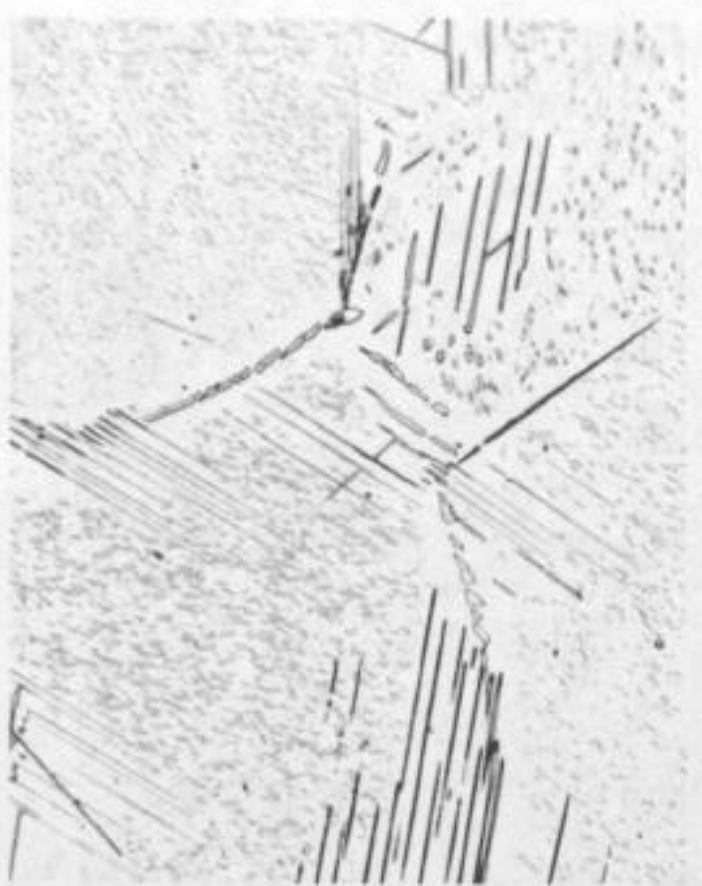

$1000 x$

24 HOURS AT $1600^{\circ} \mathrm{F}$

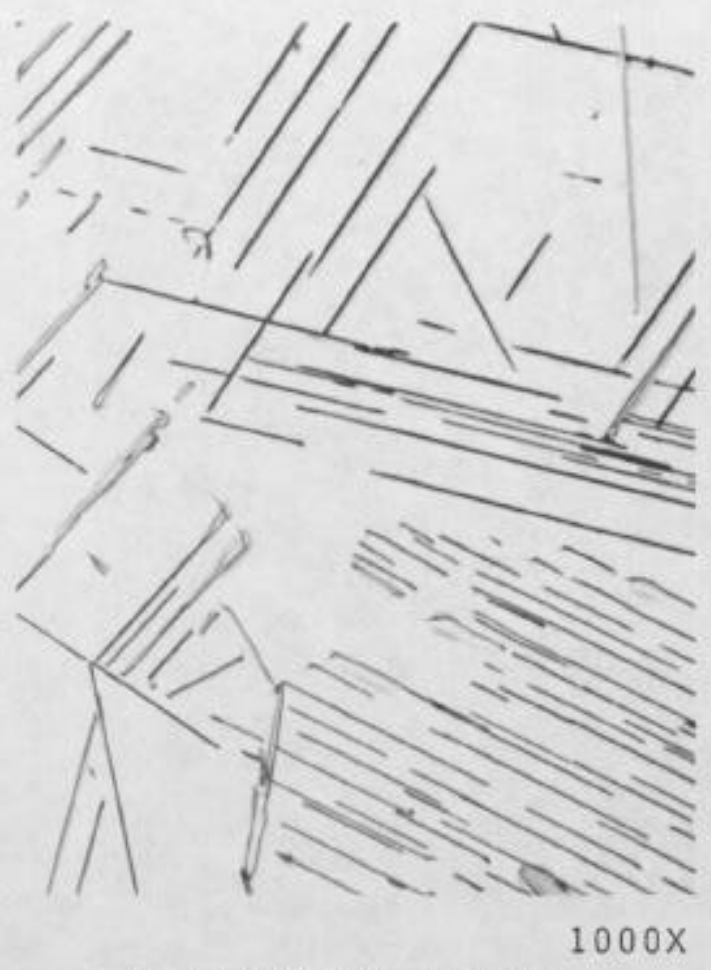

24 HOURS AT $1700^{\circ} \mathrm{F}$

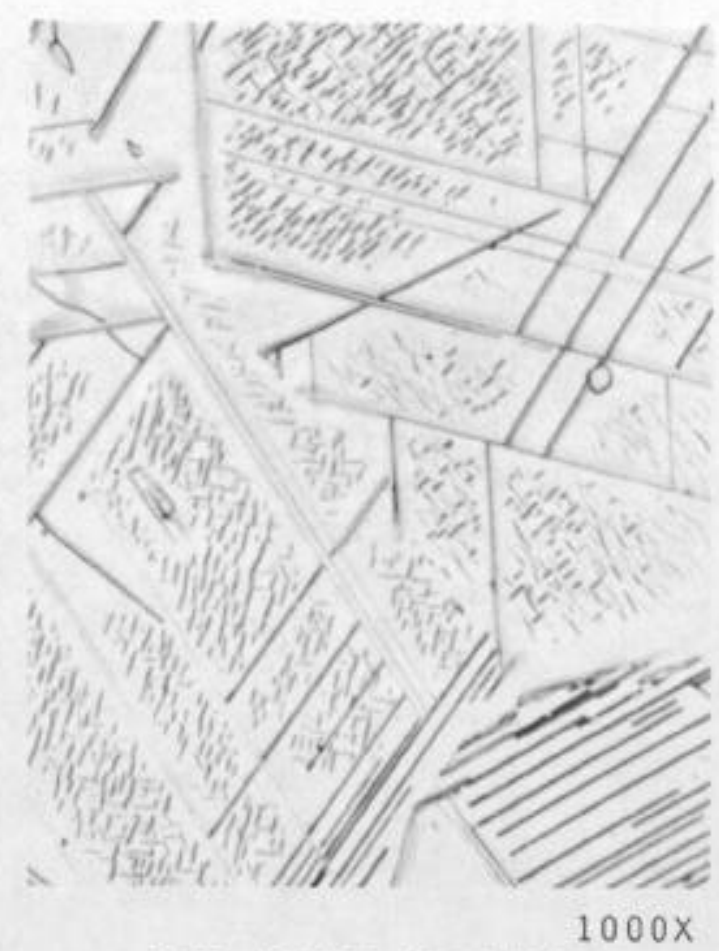

100 HOURS AT $1600^{\circ} \mathrm{F}$

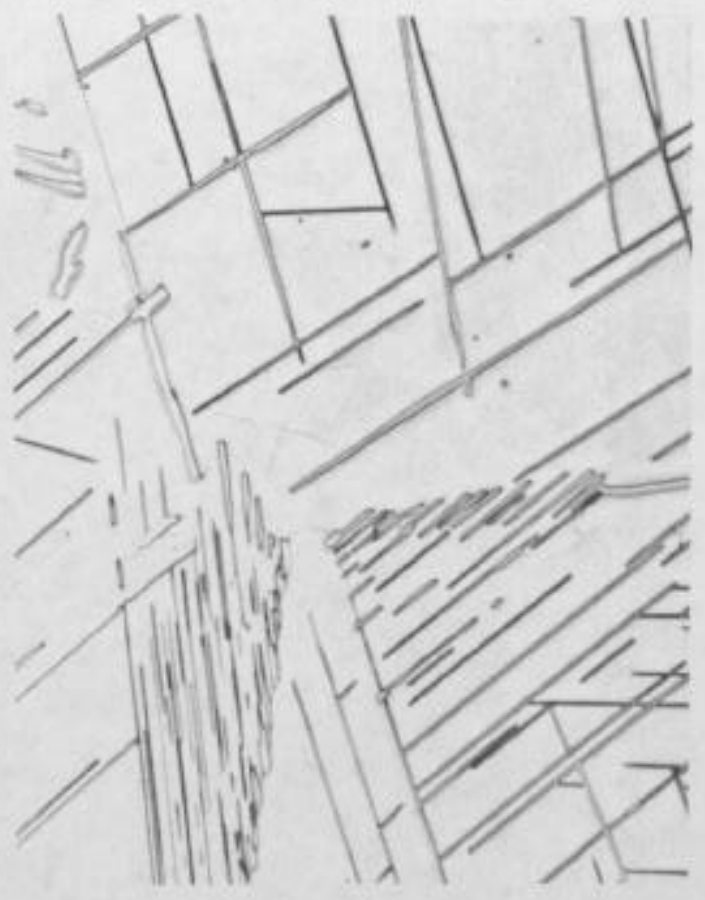

$1000 x$

100 HOURS AT $1700^{\circ} \mathrm{F}$

FIGURE 8

EFFECT OF $\mathrm{Ni}_{\mathrm{X}} \mathrm{Cb}$ PRECIPITATION UPON $\mathrm{Ni}_{3} \mathrm{Cb}$ FORMATION 


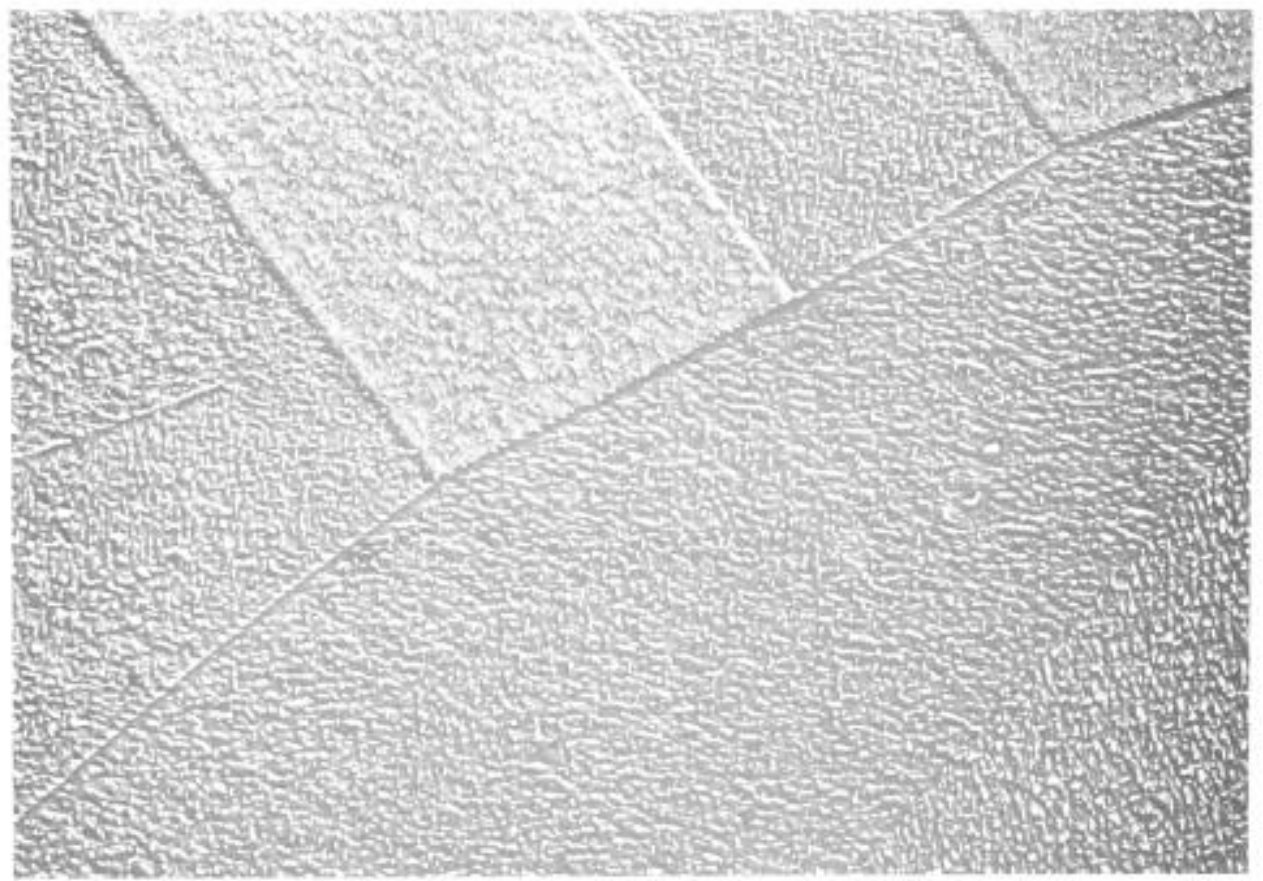

$7500 x$

\section{HOUR EXPOSURE}
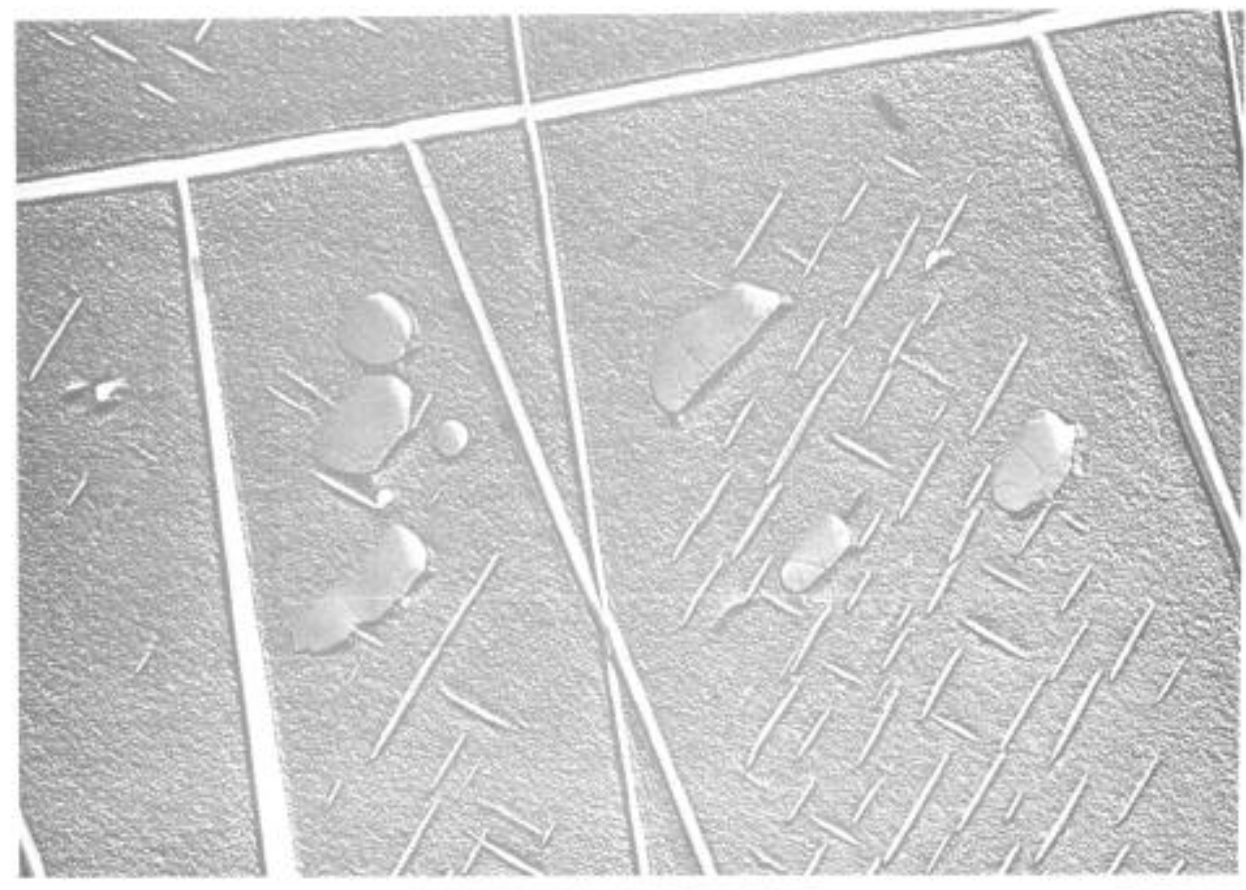

100 HOUR EXPOSURE

$7500 x$

FIGURE 9

CHANGE IN GAMMA PRIME, $\mathrm{Ni} \mathrm{i}_{\mathrm{X}} \mathrm{Cb}, \mathrm{AND} \mathrm{N} \mathrm{i}_{3} \mathrm{Cb}$

MORPHOLOGY AT $1600^{\circ} \mathrm{F}$ 


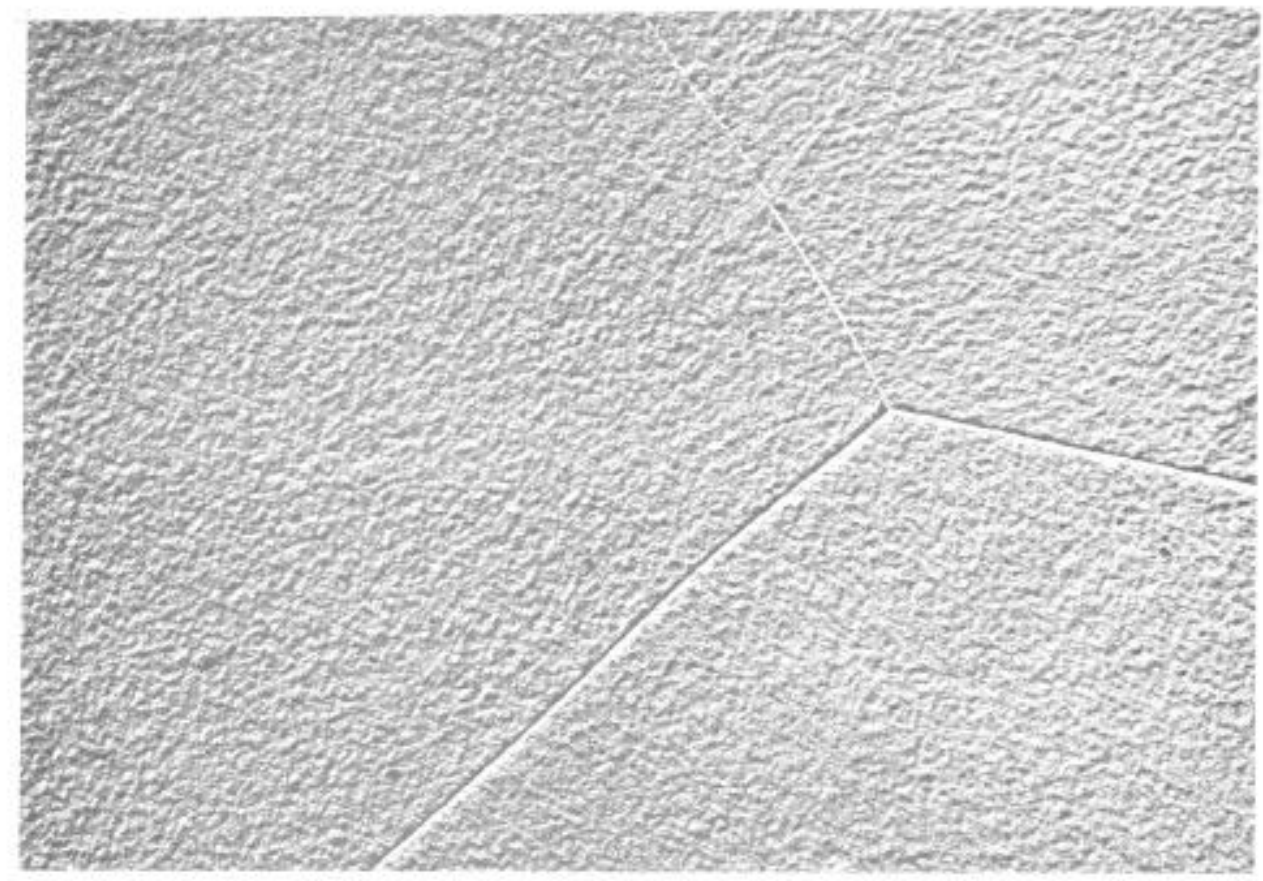

100 HOURS AT $12500 \mathrm{~F}$

$7500 x$

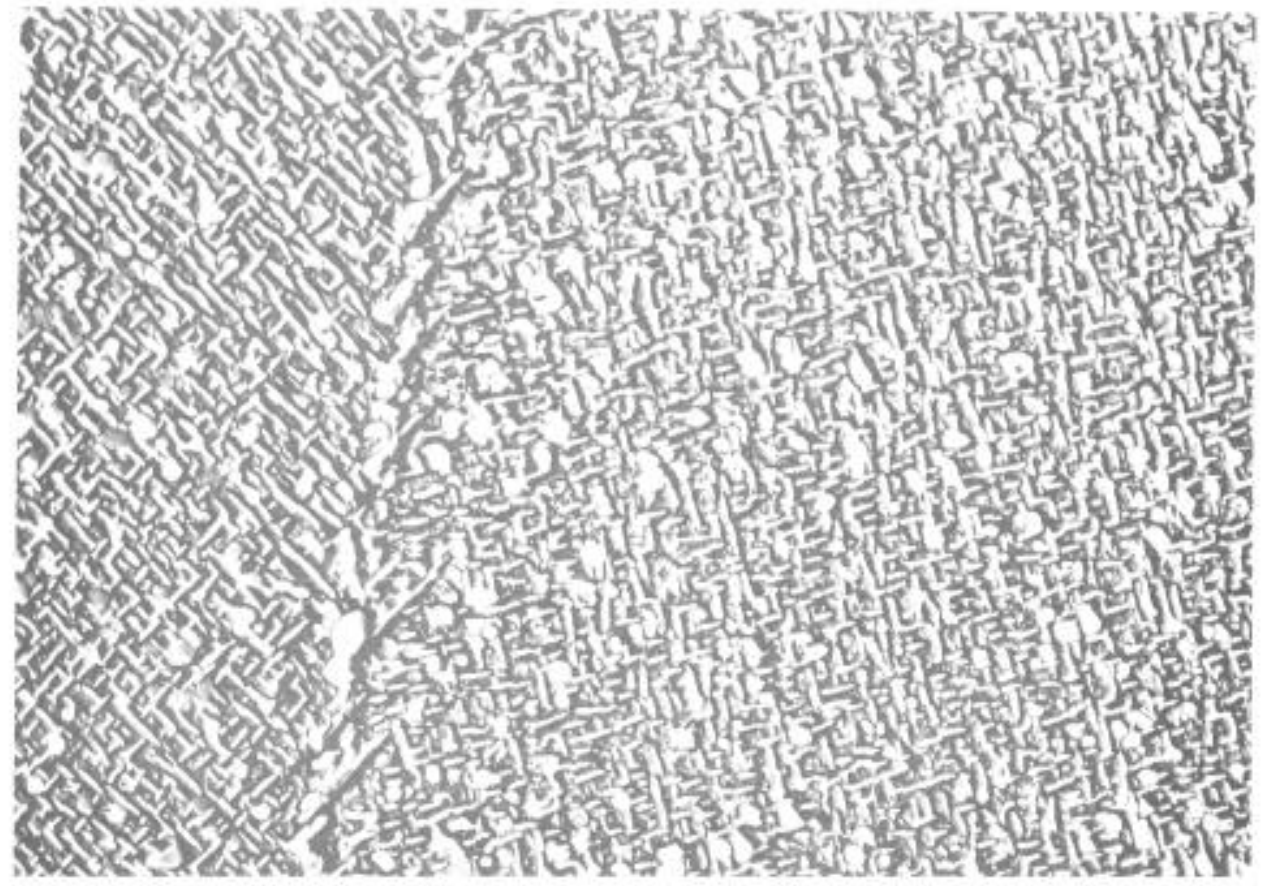

100 HOURS AT 1450 F

$7500 \times$

FIGURE 10

EFFECT OF MODERATE TEMPERATURE EXPOSURE UPON

INCONEL ALLOY 718 STRUCTURE 


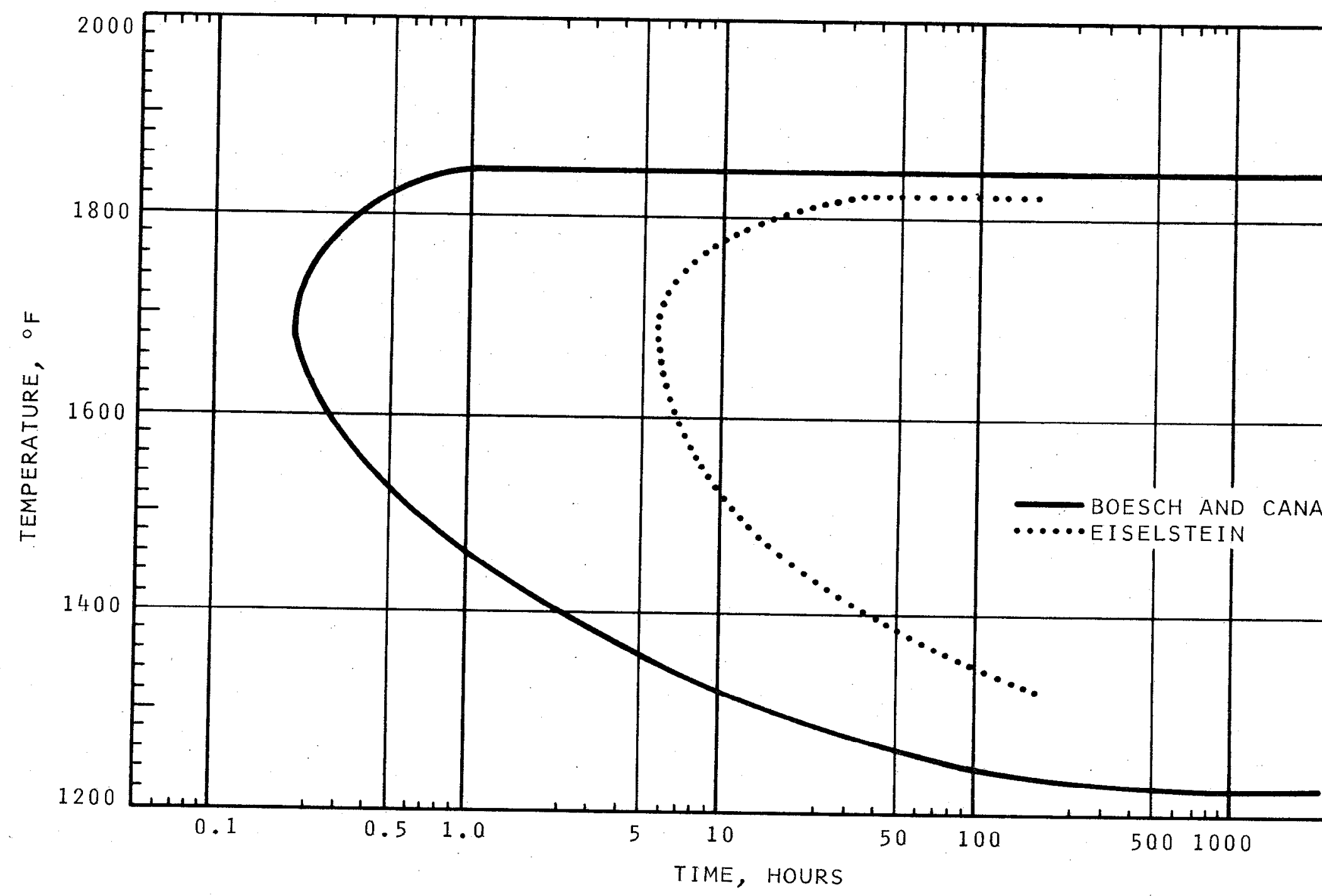

FIGURE 11 - COMPARISON OF $\mathrm{Ni}_{3} \mathrm{Cb}$ TTT CURVES 